\title{
PENERAPAN METODE PEMBELAJARAN PROBLEM SOLVING UNTUK MENINGKATKAN HASIL BELAJAR SISWA PADA MATERI KONSEP MOL DI KELAS X MIPA DI SMA NEGERI 6 KOTA BEKASI
}

\author{
Andy Novitriastuti Rahmatjati \\ rian.intan@yahoo.co.id \\ SMA Negeri 6 Bekasi
}

\begin{abstract}
The Classroom Action Research was conducted because of the low learning achievements of MOL concept and still has not done well the use of learning methods, especially in the learning process in Chemistry class of X MIPA SMAN 6 Bekasi. This research outputs indicated that Problem Solving has a positive impact in improving learning achievements of students. Based on data analysis the activity of the teacher in the learning process using Problem Solving method in each cycle also increased as well as the positive impact on the student achievement. This can be shown by the average value of student in each cycle which is constantly increasing. Thus the hypothesis of action in the study proved that the application of the problem solving method in the teaching and learning can enhance learning achievement student to learn Chemistry with the material theory of Mol concept.
\end{abstract}

Keywords: achievement, Chemistry, Concept Mol, Problem Solving Method

\begin{abstract}
ABSTRAK
Penelitian Tindakan Kelas ini dilakukan oleh karena rendahnya hasil belajar siswa pada materi konsep mol dan masih belum terlaksana dengan baik penerapan metode pembelajaran terutama pada proses pembelajaran Kimia di kelas X MIPA Sma Negeri 6 Kota Bekasi. Hasil penelitian ini menunjukkan bahwa metode pembelajaran Problem Solving memiliki dampak positif dalam meningkatkan hasil belajar siswa. Berdasarkan analisis data, aktivitas guru dalam proses pembelajaran Problem Solving dalam setiap siklus juga mengalami peningkatan serta berdampak positif terhadap prestasi belajar siswa. Hal ini dapat ditunjukkan dengan nilai rata - rata siswa pada setiap siklus yang terus mengalami peningkatan. Dengan demikian hipotesis tindakan dalam penelitian ini terbukti bahwa penerapan metode pembelajaran problem
\end{abstract}


Solving dalam proses belajar mengajar dapat meningkatkan hasil belajar siswa pada materi konsep mol.

Kata kunci: Hasil Belajar , Kimia, Konsep Mol, Metode Pembelajaran Problem Solving

\section{PENDAHULUAN}

Kegiatan belajar mengajar yang melahirkan interaksi unsurunsur manusiawi adalah sebagai suatu proses dalam rangka mencapai

tujuan

pembelajaran.Dalam kegiatan belajar mengajar dibutuhkan suatu metode pembelajaran yang menarik agar siswa tidak merasa bosan dengan materi yang diajarkan oleh guru.

Metode pembelajaran adalah cara yang dipergunakan guru dalam mengadakan hubungan dengan siswa pada saat berlangsung pembelajaran (Sudjana, 2005:76). Metode pembelajaran kimia adalah cara atau pendekatan yang dipergunakan dalam menyajikan atau menyampaikan materi pelajaran kimia, menempati peranan yang tak kalah penting dalam proses belajar mengajar. Dalam pemilihan metode apa yang tepat, guru harus melihat situasi dan kondisi siswa serta materi yang diajarkan.

Dalam kegiatan belajar mengajar daya serap peserta didik tidaklah sama. Dalam menghadapi perbedaan tersebut, strategi pengajaran yang tepat sangat dibutuhkan. Strategi belajar mengajar adalah pola umum perbuatan guru dan siswa dalam kegiatan mewujudkan kegiatan belajar mengajar. Metode pembelajaran merupakan salah satu strategi pembelajaran yang dapat dilakukan oleh guru untuk menghadapi masalah tersebut sehingga pencapaian tujuan pengajaran dapat tercapai dengan baik. Dengan pemanfaatan metode yang efektif dan efisien, guru akan mampu mencapai tujuan pengajaran.

Dalam rangka meningkatkan kualitas dan mutu pendidikan , salah satunya adalah memilih metode pembelajaran atau cara dalam menyampaikan materi pelajaran agar dapat meningkatkan hasil belajar siswa pada pelajaran Kimia . Ada banyak metode pembelajaran yang bisa digunakan guru dalam kegiatan pembelajaran, salah satunya adalah dengan menemukan masalah dan menyelesaikannya, dengan metode ini siswa akan sangat dibantu bagaimana cara menyelesaian soal - soal dalam materi konsep mol Metode pembelajaran ini juga dapat ditempuh dengan guru yang membimbing siswa untuk bersama - sama berkembang sesuai dengan taraf intelektualnya. Dan akan lebih mampu menguatkan pemahaman 
Rahmatjati, Penerapan Metode Pembelajaran Problem Solving untuk Meningkatkan Hasil Belajar Siswa pada Materi KONSEP MOL di Kelas $X$ MIPA di SMA NEGERI 6 KOTA BEKASI

siswa terhadap konsep - konsep yang diajarkan.

Berdasarkan

hasil

observasi yang penulis lakukan di kelas X MIPA SMA Negeri 6 Bekasi, salah satu penyebab turunnya hasil belajar karena siswa merasa bosan dengan metode ceramah yang diterapkan oleh guru, Metode pembelajaran adalah cara yang dipergunakan guru dalam mengadakan hubungan dengan siswa pada saat berlangsungnya pengajaran. Metode pembelajaran adalah cara - cara menyajikan materi pelajaran yang dilakukan oleh pendidik agar terjadi proses pembelajaran pada diri siswa dalam upaya untuk mencapai tujuan (Sutikno, 2009 : 88)

Metode Pembelajaran Problem Solving adalah suatu cara mengajar denganmenghadapkan siswa kepada suatu masalah agar dipecahkan ataudiselesaikan. Metode ini menuntut kemampuan untuk melihat sebabakibat, mengobservasi problem, mencari hubungan antara berbagai datayang terkumpul kemudian menarik kesimpulan yang merupakan hasilpemecahan masalah.

$$
\text { Problem/masalah yang }
$$

dihadapkan kepada siswa harusmengandung kesulitan baik yang bersifat psikis atau fisis. Maksudnyapersoalan itu memerlukan otak atau otot untuk dapat memecahkannya.Problem/masal ah yang dihadapkan siswa itu hendaklah: a) Jelas, bersih dari kesalahan dan tidak memiliki dua pengertian yangberbeda

b) Sesuai dengan kemampuan anak, tidak terlalu mudah dan juga tidak terlalu sulit sehingga tidak bisa dipecahkan oleh para siswa

c) Menarik minat anak

d) Sesuai dengan pelajaran anak diwaktu yang lalu, sekarang maupundimasa mendatang Tujuan utama digunakannya metode ini adalah untuk: memberikemampuan dan kecakapan praktis kepada siswa sehingga tidak takutmenghadapi hidup yang penuh problem serta mempunyai rasa optimisyang tinggi.Dalam kegiatan pembelajaranproblem solving denganjalan melatih siswa menghadapi berbagai masalah pribadi atauperorangan maupun masalah kelompok untuk dipecahkan sendiri atausecara bersama-sama.

Metode

Pembelajaranproblem solving (metode pemecahan masalah) bukan hanya sekedar metode mengajar, tetapi juga merupakan suatu metode berpikir, sebab dalam problem solving dapat menggunakan metode-metode lainnya yang dimulai dengan mencari data sampai kepada menarik kesimpulan. Penggunaan metode ini dengan mengikuti langkah-langkah sebagai berikut :

1) Adanya masalah yang jelas untuk dipecahkan. Masalah ini harus tumbuh dari siswa sesuai dengan taraf kemampuannya. 
2) Pencarian data atau keterangan yang dapat digunakan untuk memecahkan masalah tersebut. Misalnya, dengan jalan membaca bukubuku, meneliti, bertanya, berdiskusi, dan lain-lain.

3) Penetapan jawaban sementara dari masalah tersebut. Dugaan jawaban ini tentu saja didasarkan kepada data yang telah diperoleh,pada langkah kedua diatas.

4) Pengujian kebenaran jawaban sementara tersebut. Dalam langkah ini siswa harus berusaha memecahkan masalah sehingga betul-betul cocok. Apakah sesuai dengan jawaban sementara atau sama sekali tidak sesuai. Untuk menguji kebenaran jababan ini tentu saja diperlukan metode-metode lainnya seperti demonstrasi, tugas diskusi, dan lain-lain.

5) Penarikan kesimpulan. Artinya siswa harus sampai kepada kesimpulan terakhir tentang jawaban dari masalah tadi.

Metode
problem solving memajaran
kelebihan dan kekurangan
sebagai berikut:
Kelebihan metode pembelajaran
problem solving:

1) Metode ini dapat membuat pendidikan di sekolah menjadi lebih relevan dengan kehidupan dan lingkungan peserta didik.

2) Proses belajar mengajar melalui pemecahan masalah dapat membiasakan para siswa menghadapi dan memecahkan masalah secara terampil, apabila menghadapi permasalahan di dalam pembelajaran di kelas.

3) Metode ini merangsang pengembangan kemampuan berpikir siswasecara kreatif dan menyeluruh, karena dalam proses belajarnya,siswa banyak melakukan mental dengan menyoroti permasalahan dari berbagai segi dalam rangka mencari pemecahan.

Kekurangan metode pembelajaran problem solving

1) Menentukan suatu masalah yang tingkat kesulitannya sesuai dengan tingkat berpikir siswa, tingkat sekolah dan kelasnya serta pengetahuan dan pengalaman yang telah dimiliki siswa, sangat memerlukan kemampuan dan keterampilan guru. Sering orang beranggapan keliru bahwa metode pemecahan masalah hanya cocok untuk SLTP, SLTA, dan PT saja. Padahal, untuk siswa SD sederajat juga bisa dilakukan dengan tingkat kesulitan permasalahan yang sesuai dengan taraf kemampuan berpikir anak.

2) Proses belajar mengajar dengan menggunakan metode ini sering memerlukan waktu yang cukup banyak.

3) Mengubah kebiasaan siswa belajar dengan mendengarkan dan menerima informasi dari guru menjadi belajar dengan banyak berpikir memecahkan permasalahan sendiri atau kelompok, yang kadang-kadang memerlukan berbagai sumber belajar, merupakan kesulitan tersendiri bagi siswa. 
Rahmatjati, Penerapan Metode Pembelajaran Problem Solving untuk Meningkatkan Hasil Belajar Siswa pada Materi KONSEP MOL di Kelas $X$ MIPA di SMA NEGERI 6 KOTA BEKASI

Dengan demikian pembelajaran problem solving dalam pelajaran kimia dapat tercipta suasana pembelajaran yang efektif dan dapat meningkatkan belajar siswa

Dari hasil ulangan harian yang telah dilaksanakan dapat diketahui bahwa siswa kelass $X$ MIPA yang berjumlah 40 siswa. Persentase siswa yang mencapai indikator keberhasilan hasil belajar belum mencapai kriteria ketuntasan yang telah ditetapkan yaitu $85 \%$. Persentase siswa yang mencapai nilai $\geq 70$ masih $64 \%$. Hal ini dikarenakan proses pembelajaran masih berpusat pada guru sehingga siswa kurang termotivasi untuk belajar lebih serius. Berdasarkan uraian tersebut di atas ,penulis mencoba menerapkan salah satu metode pembelajaran, yaitu metode pembelajaran Problem Solving. Hal ini dilakukan untuk mengetahui apakah metode pembelajaran problem solving dapat meningkatkan hasil belajar kimia pada materi konsep mol. Pemilihan metode pembelajaran ini dimaksudkan agar siswa dapat menyelesaikan masalah dalam materi konsep mol. Dalam metode problem solving siswa akan lebih aktif dalam memecahkan masalah sedangkan guru berperan sebagai fasilitator atau memberikan petunjuk cara memecahkan masalah dalam pelajaran kimia.

\section{METODE PENELITIAN}

Penelitian Tindakan Kelas (PTK) adalah suatu bentuk kajian yang bersifat sistematis refletif oleh pelaku tindakan untuk memperbaiki kondisi pembelajaran yang dilakukan (Muklis , 2000 : 5) Penelitian ini merupakan penelitian tindakan (action research), karena penelitian dilakukan untuk mengetahui permasalahan dalam pembelajaran di kelas. Penelitian Tindakan Kelas merupakan Penelitian deskriptif karena menggambarkan suatu tehnik pembelajaran dapat diterapkan dan bagaimana hasil yang diinginkandapatdicapai.

Penelitian tindakan ini menggunakan bentuk guru sebagai peneliti. Tujuan utama dari penelitian tindakan ini adalah meningkatkan hasil pembelajaran di kelas dimana guru secara penuh terlibat dalam penelitian, mulai dari perencanaan ,tindakan, pengamatan dan refleksi. Salah satu tujuan penilaian yaitu diagnostic , dimana guru mengadakan diagnose kepada siswa tentang kebaikan dan kelemahannya, dengan diketahui sebab - sebab kelemahan ini maka akan lebih mudah mencari cara untuk mengatasinya dan tujuan mengukur keberhasilan yaitu untuk mengetahui sejauh mana suatu program berhasil diterapkan (Arikunto, $1997: 9$ )

Tehnik pengumpulan data dalam penelitian ini adalah berupa observasi, tes, dan studi dokumentasi. Dalam penelitian ini peneliti adalah guru yang masuk kelas sebagai pengajar tetap dan 
dilakukan seperti biasa, sehingga siswa tidak tahu jika sedang diteliti. Cara ini diharapkan didapatkan data yang obyektif dan kevalidan data bisa diperlukan. Penelitian ini akan dihentikan apabila ketuntasan belajar secara klasikal telahmencapai $85 \%$ atau lebih. Jadi dalam penelitian ini penulis tidak tergantung kepada banyaknya siklus yang harus dilalui.

Penelitian tindakan kelas ini dilaksanakan di SMA Negeri 6 Kota Bekasi pada semester 2 tahun pelajaran 20152016 yaitu dari tanggal 13 Januari 2016 sampai tanggal 17 Februari 2016 sesuai dengan kalender pendidikan atau kalender akademik sekolah serta Rencana Program Pembelajaran (RPP) yang telah guru/peneliti buat. Subjek penelitian adalah siswa kelas X MIPA SMA Negeri 6 Kota Bekasi Tahun Pelajaran 2015-2016 adalah 40 orang.

Secara garis besar penelitian tindakan kelas yang telah dilaksanakan terdiri dari 2 (dua) siklus, masing-masing siklus terdiri dari 4 (empat) tahapan yakni perencanaan, pelaksanaan, pengamatan, dan refleksi.

Tindakan pembelajaran pada siklus I yakni mengkonversi jumlah mol ke dalam jumlah partikel, jumlah massa, dan jumlah volume zat. Sedangkan tindakan pembelajaran pda siklus II yakni mengenai rumus empiris, rumus molekul, dan pereaksi pembatas. Adapun deskripsi tindakan yang telah dilakukan adalah sebagai berikut:

\section{Siklus I}

a. Tahap Perencanaan

- Membuat Rencana

Pelaksanaan

Pembelajaran (RPP)

dengan menggunakan

pendekatan problem

solving.

- Membuat Lembar Kerja Siswa (LKS) yang di dalamnya terdapat ringkasan materi, contoh soal yang disertai dengan tahapan pemecahan masalah, dan latihan soal.

- Membuat instrumen yang akan digunakan dalam siklus PTK seperti instrumen tes, lembar observasi dan angket.

b. Tahap Pelaksanaan

Dalam melaksanakan kegiatan pembelajaran, guru yang bertindak sebagai peneliti berusaha menerapkan kegiatan pembelajaran yang telah disusun dalam rencana pelaksanaan pembelajaran (RPP). Pembelajaran dalam kelas dilaksanakan sebanyak 3 kali pertemuan yaitu pada tanggal 11, 18, dan 28 Januari 2016. Setiap pertemuan berlangsung selama $2 \times 45$ menit. Adapun materi yang disampaikan pada siklus I adalah mengkonversi jumlah mol ke dalam jumlah partikel, mssa zat, dan volume zat serta hipotesis avogadro.

Guru membimbing siswa dengan pendekatan pemecahan masalah yaitu bagaimana siswa berfikir cara 
Rahmatjati, Penerapan Metode Pembelajaran Problem Solving untuk Meningkatkan Hasil Belajar Siswa pada Materi KONSEP MOL di Kelas $X$ MIPA di SMA NEGERI 6 KOTA BEKASI

menyelesaikan maslah dengan menggunakan 4 (empat) tahap pemecahan masalah yaitu menganalisis, merencanakan, melakukan perhitungan, dan mengevaluasi jawaban. Pada saat guru (peneliti) dan siswa melukan kegiatan pembelajaran, observer atau kolaborator melakukan pengamatan terhadap aktivitas guru dan siswa di kelas. Dengan menggunakan lembar observasi, observer mengamati aktivitas siswa dan guru berdasarkan aktivitas-aktivitas yang tampak dan berdasarkan kriteria penilaian yang telah ditetapkan serta memberikan catatan tambahan mengenai peroses pembelajaran berlangsung.

c. Pengamatan

Pada tahap pengamatan diperoleh hasil sebagai berikut:

- Rata-rata skor post test siswa adalah 70,53, dari hasil tersebut menunjukkan bahwa hasil belajar siswa dan persentase masih $64,00 \%$ siswa yang memperoleh nilai $\geq 70$. Angka ini masih belum mencapai target yang ditetapkan yaitu rata-rata hasil evaluasi harus mencapai $\geq 70$ dan minimal $85 \%$ siswa yang mendapatkan nilai $\geq 70$.

- Persentase tahap analisis siswa yaitu 95\%, tahap perencanaan $84 \%$, tahap perhitungan $61 \%$ dan tahap pengecekan $64 \%$

- Lembar observasi aktivitas siswa diperoleh data lebih dari 505 siswa memperhatikan guru menjelaskan, kurang dari $50 \%$ siswa yang bertanya ketika dipersilahkan, lebih dari $50 \%$ siswa mengerjakan soal dengan tahapan pemecahan masalah, kuraang dari $50 \%$ berdiskusi dengan teman sebangkunya dan sekitar $50 \%$ siswa mengerjakan latihan soal yang diberikan.

- Pada pertemuan kedua siklus I, perubahan hanya terjadi pada kegiatan mengerjakan latihan soal. Siswa yang langsung mengerjakan soal yang diberikan oleh guru meningkat menjadi lebih dari $50 \%$.

- Sebagian siswa masih belum tepat membuat suatu kesimpulan pada tahap pengecekan

- Siswa masih sungkan untuk maju mengerjakan soal di papan tulis

- Hampir 50\% siswa menyatakan bahwa penyampaian materi oleh guru terlalu cepat

d. Refleksi

$\begin{array}{lrr}\text { Persentase } & \text { siswa } \\ \text { yang mencapai } & \text { indikator } \\ \text { keberhasilan hasil } & \text { belajar } \\ \text { belum mencapai } & \text { kriteria } \\ \text { ketuntasan yang } & \text { telah } \\ \text { ditetapkan yaitu } & 85 \% \text {. } \\ \text { Persentase siswa } & \text { yang } \\ \text { mencapai nilai } \geq 70 & \text { masih }\end{array}$


64\%. Hal ini dikarenakan proses pembelajaran masih berpusat pada guru sehingga siswa kurang termotivasi untuk belajar lebih serius. Oleh karena itu hasil belajar dan aktivitas siswa perlu ditingkatkan melalui tindakan pembelajaran pada siklus II.

Sebagi langkah untuk menindaklanjuti proses pembelajaran pada siklus I, perlu adanya perbaikan dengan tindakan pada siklus II. Adapun perbaikan yang dilakukan pada siklus berikutnya adalah sebagai berikut:

1) Tindakan-tindakan pada siklus I yang sudah baik tetap dipertahankan.

2) Pada fase latihan terbimbing, peneliti mencoba memberikan tugas kelompok dan diharapkan interaksi antar siswa menjadi meningkat dan siswa lebih aktif membantu teman yang belum mengerti dalam kelompok.

3) Guru lebih meningkatkan um;pan balik kepada siswa agar lebih termotivasi dalam pembelajaran.

4) Lebih banyak memberikan soal-soal latihan untuk dikerjakan di rumah.

5) Lebih menekankan penggunaan tahap=tahap pemecahan masalah terutama dalam

\section{Siklus II}

Tahapan-tahapan

siklusll diuraikan sebagai berikut:

a. Perencanaan

Meninjau kembali rancangan pembelajaran yang disiapkan untuk siklus II dengan melakukan revisi dan perbaikan - perbaikan sesuai hasil siklus I.

b. Pelaksanaan

Dalam melaksanakan pembelajaran, guru berusaha menerapkan kegiatan pembelajaran yang telah disusun dalam rencana pelaksanaan pembelajaran (RPP). Seperti halnya siklus I, pada siklus II ini pembelajaran dilaksanakan di dalam kelas sebanyak 3 kali pertemuan dengan durasi masing-masing $2 \times$ 45 menit. Adapun materi yang disampaikan pada siklus II adalah perhitungan rumus empiris, rumus molekul, kadar senyawa, dan pereaksi pembatas beserta cara-cara penentuannya secara bertahap yang diawali dengan pemberian materi, contoh soal, dan latihan soal.

Pada siklus II, guru memberikan latihan soal yang dikerjakan secara berkelompok untuk meningkatkan aktivitas siswa yang mana diharapkan akan adanya interaksi antar siswa dalam memahami materi yang 
Rahmatjati, Penerapan Metode Pembelajaran Problem Solving untuk Meningkatkan Hasil Belajar Siswa pada Materi KONSEP MOL di Kelas $X$ MIPA di SMA NEGERI 6 KOTA BEKASI

diberikan oleh guru sehingga siswa yang sudah paham dapat membantu temannya yang belum paham.

Tindakan siklus II ini diakhiri dengan mengulas materi dan membahas soal bersama-sama, setelah itu guru memberikan post test untuk mengetahui pengetahuan siswa setelah pembelajaran.

c. Pengamatan Hasil observasi pada siklus II adalah sebagai berikut:

- Rata-rata skor post test siswa adalah 77,87, ini menunjukkan bahwa indikator ketercaoaian hasil belajar yang ditetapkan sudah terpenuhi yaitu $\geq 75$.

- Persentase ketuntasan belajar siswa telah mencapai $88 \%$ sehingga sudah melebihi target yang ditetapkan yaitu $85 \%$ siswa memperoleh nilai $\geq 70$.

- Pelaksanaan tahaptahap problem solving sudah meningkat yaitu pada tahap analisis meningkat menjadi 98\% dari siklus I yaitu $95 \%$.

- Tahap perencanaan meningkat menjadi $91 \%$ dari siklus I yaitu $84 \%$.

- Tahap perhitungan dari $61 \%$ pada siklus I meningkat menjadi $71 \%$ pada siklus II.

- Tahap pengecekan meningkat dari $64 \%$ pada siklus I menjadi $68 \%$ pada siklus II.

- Pada pertemuan pertama siklus II, abru sekitar $50 \%$ siswa memperhatikan guru menjelaskan. Sekitar $50 \%$ siswa yang bertanya sat diberi kesempatan. Lebih dari $50 \%$ siswa mengerjakan soal latihan yang diberikan. Sekitar 50\% siswa berdiskusi saat mengerjakan soal. Lebih dari $50 \%$ siswa mengerjakan soal dengan menggunakan tahapan pemecahan masalah.

- Pada pertemuan kedua siklus II, siswa yang memperhatikan guru menjelaskan masih sekitarn $50 \%$ sedangkan aktivitas siswa yang lain seperti mengajukan pertanyaan dan berdiskusi meningkat menjadi lebih dari 50\% siswa. Aktivitas siswa yang mengerjakan latihan soal yang diberikan dan mengerjakan dengan tahapan pemecahan masalah menjadi lebih dari $50 \%$.

d. Refleksi

Pada siklus II ini terjadi peningkatan ratarata nilai hasil evaluasi yaitu 77,87 dan $88 \%$ siswa yang memperoleh nilai $\geq 70$. Dengan demikian 
target yang telah ditetapkan oleh peneliti telah tercapai. Selain itu terdapat peningkatan pemahaman mengenai tahap-tahap pemecahan masalah dari siklus I ke siklus II. Sikap dan aktivitas siswa dari siklus I ke siklus II juga meningkat.

Setelah dilakukan tindakan pembelajaran dengan menggunakan metode problem solving pada siklus II diperoleh hasil sebagai berikut:

1) Ketercapaian ketuntasan belajar siswa dari siklus I ke siklus II telah terjadi peningkatan pada siklus II.

2) Siswa sudah mampu menyelesaikan soal dengan metode problem solving .

3) Siswa merasa senang selama proses pembelajaran dengan metode problem solving karena mereka dapat meningkatkan

kemampuan mereka dengan latihan-latihan yang diberikan.

4) Pada siklus II diperoleh ketuntasan dan aktivitas belajar siswa yang meningkat dan telah mencapai indikator keberhasilan yang telah ditetapakan. Oleh karenan itu peneliti memutuskan untuk menghentikan penelitian pada siklus II ini.
Berdasrkan hasil penelitian yang dilakukan di kelas X SMAN 6 Kota Bekasi pada materi konsep mol dengan menggunakan metode pembelajaran problem solving , selama pembelajaran berlangsung secara keseluruhan dari siklus I ke siklus II diperoleh data sebagai berikut:

1) Hasil belajar siswa Berdasarkan hasil belajar siswa dari pada siklus I dan siklus II diperoleh data seperti pada tabel 4.1 berikut.

Tabel 4.1 : Hasil belajar siswa

\begin{tabular}{|c|c|c|}
\hline Siklus & $\begin{array}{c}\text { Rata- } \\
\text { rata } \\
\text { nilai }\end{array}$ & Persentase \\
\hline I & 70,53 & 64 \\
\hline II & 77,87 & 88 \\
\hline
\end{tabular}

2) Tingkat pemahaman siswa

Dari hasil pembelajaran pada siklus I dan siklus II terjadi peningkatan pemahaman siswa dalam menerapkan tahap-tahap pemecahan masalah seperti pada Grafik 1. 
Rahmatjati, Penerapan Metode Pembelajaran Problem Solving untuk Meningkatkan Hasil Belajar Siswa pada Materi KONSEP MOL di Kelas $X$ MIPA di SMA NEGERI 6 KOTA BEKASI

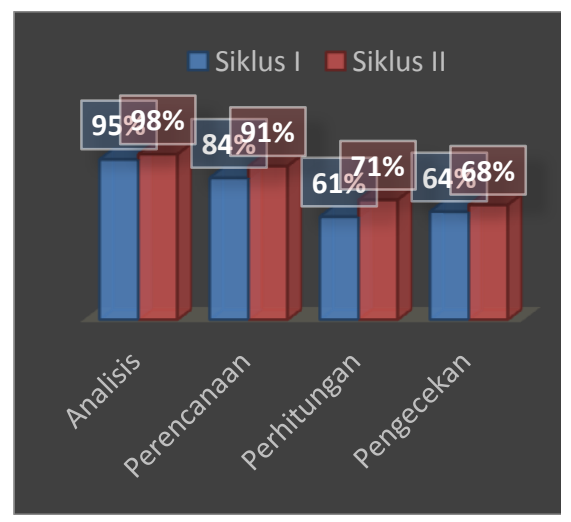

Grafik 1. Tingkat Pemahaman Siswa

3) Sikap siswa

a) Sikap siswa terhadap proses pembelajaran Peningkatan sikap siswa terhadap proses pembelajaran yang mereka ikuti dari siklus I ke siklus II dapat di visualisasikan dalam bentuk Grafik 2 .

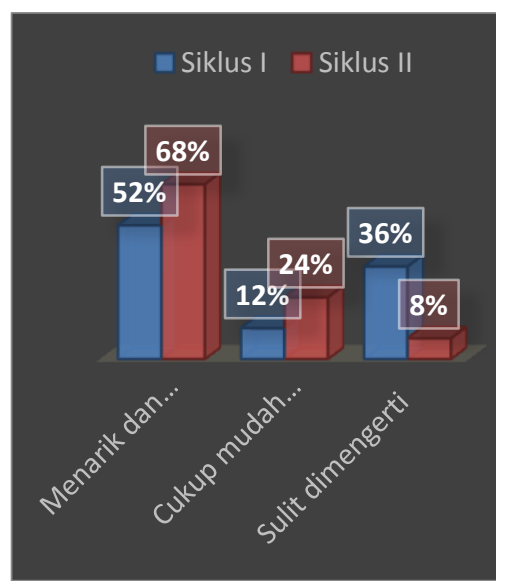

Grafik 2. Sikap siswa terhadap proses pembelajaran b) Sikap siswa terhadap materi pelajaran

Peningkatan sikap siswa terhadap materi pelajaran dari siklus I ke siklus II dapat di visualisasikan dalam bentuk Grafik 3.

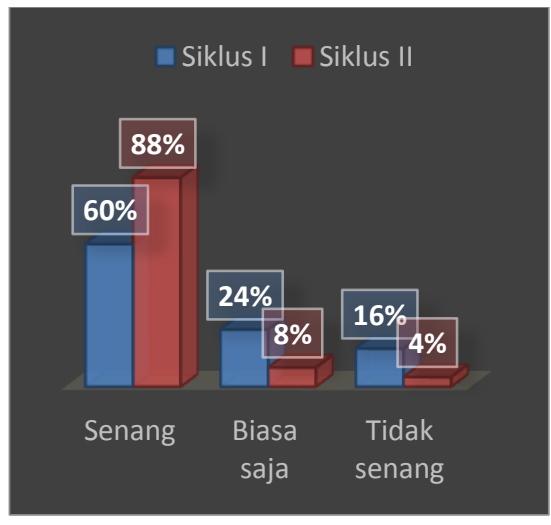

Grafik 3. Sikap siswa terhadap minat pada materi pelajaran

c) Sikap siswa terhadap cara guru menyampaikan materi pelajaran

Peningkatan sikap siswa terhadap cara guru menyampaikan materi pelajaran dari siklus I ke siklus II dapat di visualisasikan dalam bentuk Grafik 4. 


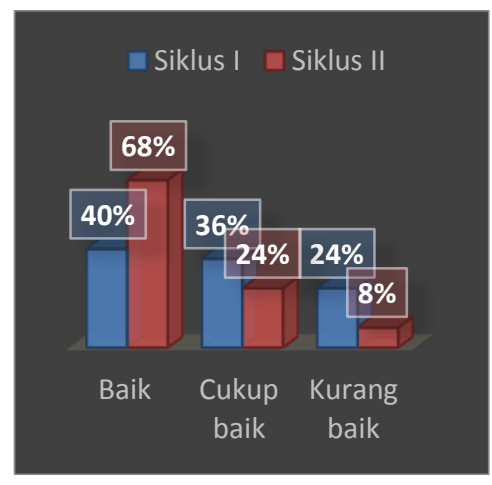

e) Sikap siswa terhadap evaluasi yang diberikan guru Peningkatan sikap siswa terhadap evaluasi yang diberikan guru dari siklus I ke siklus II dapat di visualisasikan dalam bentuk Grafik 6.

Grafik 4. Sikap siswa terhadap cara guru menyampaikan pelajaran

d) Sikap sikap terhadap pemahaman materi yang dipelajari Peningkatan sikap siswa terhadap pemahaman materi yang dipelajari dari siklus I ke siklus II dapat di visualisasikan dalam bentuk Grafik 5.

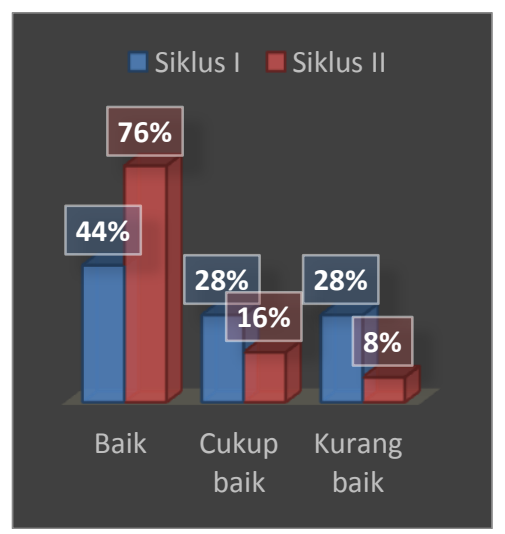

Grafik 5. Sikap siswa terhadap cara guru menyampaikan pelajaran

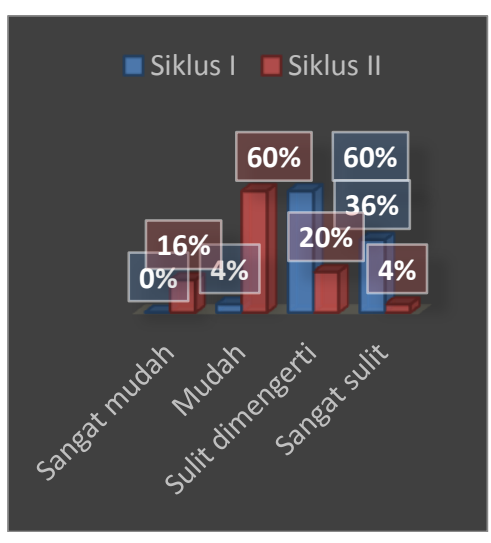

Grafik 6. Sikap siswa terhadap cara guru menyampaikan pelajaran

\section{KESIMPULAN}

Berdasarkan hasil penelitian dan pembahasan yang telah diuraikan sebelumnya, dapat diambil kesimpulan bahwa setelah dilakukan kegiatan pembelajaran dengan menggunakan pendekatan problem solving dengan 4 (empat) tahapan yaitu analisis dimana siswa terlebih dahulu memahami masalah dengan mengumpulkan data yang diperoleh dan menentukan 
Rahmatjati, Penerapan Metode Pembelajaran Problem Solving untuk Meningkatkan Hasil Belajar Siswa pada Materi KONSEP MOL di Kelas $X$ MIPA di SMA NEGERI 6 KOTA BEKASI

inti permasalahan yang harus dipecahkan. Selanjutnya membuat sebuah perencanaan dengan menentukan langkah-langkah ataupun rumus-rumus yang akan digunakan untuk menyelesaikan permaslahan tersebut, selanjutnya melakukan perhitungan sesuai dengan langkahlangkah ataupun rumusrumus yang digunakan, dan terakhir pengecekan melakukan mengetahui ketepatan jawabaan yang diperoleh. Hasil belajar kimia siswa pada materi konsep mol dari siklus I ke siklus II mengalami peningkatan.

Dari

proses

pembelajaran pada siklus I dan II didapatkan nilai ratarata hasil belajar pada post test I adalah 70,53 dan persentase siswa yang mencapai nilai $\geq 70$ adalah $64 \%$. Setelah dilakukan perbaikan-perbaikan pada tahap-tahap penyelesaian masalah, ringkasan materi yang diberikan kepada siswa, cara penyampaian materi oleh guru, metode pembelajaran yang dilakukan pada siklus II, rata-rata hasil post test siswa mencapai 77,87 dan persentase siswa yang mendapatkan nilai $\geq 70$ adalah $88 \%$. Angka ini sudah cukup bahkan melebihi dari batas ketercapaian yang ditentukan. Artinya bahwa penelitian ini dapat dikatakan berhasil.
Sebagai tindak lanjut dari hasil penelitian ini, peneliti mencoba mengemukakan beberapa saran sebagai berikut:

1. Metode pembelajaran problem solving dapat diterapkan sebagai salah satu alternatif dalam pelaksanaan

pembelajaran kimia.

Namun pembelajaran problem solving ini harus disesuaikan dengan materi atau konsep yang dipilih.

2. Penerapan pembelajaran problem solving dapat dikolaborasikan dengan model pembelajaran lain seperti pembelajaran kooperatif sehingga siswa dapat lebih aktif dalam proses pembelajaran.

3. Kelengkapan media pembelajaran juga dapat membantu guru dalam menerapkan

pembelajaran problem solving ini sehingga tujuan pembelajaran akan tercapai dengan lebih baik.

4. Mengingat penelitian ini masih sangat sederhana, apa yang didapat dari hasil penelitian ini dapat dijadikan sebagai dasar untuk penelitian lanjutan.

\section{ACUAN PUSTAKA}

Arikunto, Suharsimi dkk, (2008). Penelitian Tindakan Kelas. (Jakarta: Bumi Aksara) 
Farkhatin, N, (2008). Efektifitas pembelajaran problem solving dengan menggunakan alat peraga pada materi aritmatika soasial pada peserta didik kelas VII semester I MTS NU 01 Tarub Tegal tahun ajaran 2008/2009. Skripsi sarjana IAIN Walisongo Semarang. (Semarang: Perpustakaan IAIN Walisongo Semarang, 2010)

Harjani, T, (2012). Kimia Untuk SMA/MA Kelas $X$, (Sidoarjo: PT. BuanaMasmedia Pustaka)

Huda M.U, (2008). Model pembelajaran problem solving untuk meningkatkan hasil peserta didik pada materi pokok limit fungsi kelas XI semester II SMAN 1 Mranggen tahun pelajaran 2008/2009. Skripsi Sarjana IAIN Walisongo, (Semarang: Perpustakaan IAIN Walisongo Semarang, 2010)

M. Sobri Sutikno. 2009, Psikologi Belajar. Jakarta: PT Raja Grafindo Persada

Mukhlis, A. (Ed). 2000. Penelitian tindakan kelas. Makalah Panitia Pelatihan Penulisan Karya IImiah untuk Guru-guru seKabupaten Tuban.
Rahmawati, N, (2009), Efektifitas model pembelajaran problem solving dalam materi sistem persamaan linier dua variabel di kelas VIII MTsN Tanjung Tani Prambon Nganjuk tahunajaran 2009/2010. (Semarang: Perpustakaan IAIN Walisongo Semarang. 2010)

Slameto, (1995), Belajar dan Faktor-faktor yang Mempengaruhinya,(Jakart a:Rineka Cipta)

Sugiyono, (2002), Metode Penelitian Pendidikan: Pendekatan Kuantitatif,Kualitatif danR $\& B$, (Bandung: Alfabeta)

Syaiful Sagala, (2003), Konsep dan Makna Pembelajaran, (Bandung: Alfabeta)

Suprihatiningrum, J, (2013). Strategi Pembelajaran : Teori dan Aplikasi,(Jogjakarta: ArRuzz Media)

Wiriaatmadja, R, (2012). Metode Penelitian Tindakan Kelas, (Bandung: PT. Remaja Rosdakarya)

Yudhistira, D, (2013). Menulis Penelitian Tindakan Kelas Yang Apik (Asli Perlullmiah Konsisten), (Jakarta: PT. Gramedia Widiasarana Indonesia) 